\title{
Teaching for a transformative engagement with our context: The importance of care in Christian pedagogical suggestions for higher education
}

\begin{abstract}
Author:
Helena Hoogstad ${ }^{1}$

Affiliation:

${ }^{1}$ Department of Theology and Philosophy, North-West University, Vaal Triangle Campus, South Africa

Correspondence to: Helena Hoogstad

Email:

helena.hoogstad@gmail.com

Postal address:

PO Box 1174, Vanderbijlpark

1900 , South Africa
\end{abstract}

Dates:

Received: 02 Sept. 2013

Accepted: 28 Oct. 2013

Published: 13 Dec. 2013

How to cite this article: Hoogstad, H., 2013, 'Teaching for a transformative engagement with our context: The importance of care in Christian pedagogical suggestions for higher education', Koers - Bulletin for Christian Scholarship 78(2), Art. \#2142, 11 pages. http://dx.doi.org/10.4102/ koers.v78i2.2142

Note:

The author of this article is also the current editorin-chief of Koers - Bulletin for Christian Scholarship. However, in the case of this edition and for this article a guest editor, Renato Coletto, was responsible for all the editorial work and the decisions regarding this article's review and placement.

\section{Copyright:}

C 2013. The Authors.

Licensee: AOSIS

OpenJournals. This work

is licensed under the

Creative Commons

Attribution License.

Read online:
Responsible scholarship requires that students engage with their context and their own learning to understand and transform our world with wisdom. Ponti (J.J.) Venter argues that such a notion is central in understanding the task of a (Christian) university. In this article, dedicated to Professor Venter, I argue that the pedagogical implications of such a Christian understanding of science need to be developed further in a higher education context. I propose that care deepens wonder and sustains action by continuously calling our imagination to envisage longed-for change in both an academic and a broader social context. I offer five concrete suggestions to support lecturers in guiding students to act from their care for the world. These suggestions refer to the importance of inventory work, the cultivation of empathy, inspiring examples, emotional involvement, and an inner and outer dialogue as to the appropriate form their care should take. A Christian pedagogy should, secondly, support students in unfolding their own style of moving between theory and experience; thirdly, it should enable students to experience themselves as partners in academic discussions and as historical formative agents contributing to our world; fourthly, it should focus on a view of the world in which their tentacles are feeling for change, accompanied by normative sophistication. Fifthly, the development of a suitable pedagogy requires lecturers to develop peer groups organically to reflect on teaching practices that encourage students' transformative engagement with our world.

Onderrig vir ' $n$ transformatiewe betrokkenheid by ons konteks: Die belangrikheid van omgee in Christelike pedagogiese voorstelle vir hoër onderwys. Verantwoordelike wetenskap vereis dat studente betrokke is by hulle konteks sowel as hulle eie leer sodat hulle ons wêreld met wysheid kan verstaan en transformeer. Ponti (J.J.) Venter argumenteer dat so 'n idee sentraal is in die verstaan van 'n (Christelike) universiteit. In hierdie artikel, opgedra aan Professor Venter, argumenteer ek dat die pedagogiese implikasies van so 'n Christelike verstaan van wetenskap verder ontwikkel behoort te word in 'n hoër onderwyskonteks. Omgee lei tot ' $n$ verdieping van wonder en onderhou aktiewe optrede deur ons verbeelding voortdurend op te roep om daardie verandering waarna gehunker word in beide ' $n$ akademiese en breër sosiale konteks voor oë te stel. Ek bied vyf konkrete voorstelle om dosente te ondersteun in die begeleiding van studente se omgee vir die wêreld. Hierdie voorstelle wys op die belangrikheid van inventaris-werk, die kweek van empatie, inspirerende voorbeelde, emosionele betrokkenheid en 'n innerlike en eksterne dialoog oor die gepaste vorm vir hulle omgee. 'n Christelike pedagogie behoort in die tweede plek studente te ondersteun om hulle eie styl van beweging tussen teorie en ervaring te ontvou; derdens behoort dit studente in staat te stel om hulleself as vennote in akademiese besprekings en historiese formatiewe agente wat bydraes tot ons wêreld lewer, te beskou; vierdens sal dit fokus op 'n siening van die werklikheid waarin studente se tentakels na verandering voortvoel, vergesel van normatiewe sofistikasie. Vyfdens vereis die ontwikkeling van 'n gepaste pedagogie dat dosente op organiese wyse eweknie-groepe ontwikkel om te reflekteer op onderrigpraktyke wat studente se transformatiewe betrokkenheid by ons wêreld aanmoedig.

Behold, a sower went forth to sow; and when he sowed,

some seeds fell by the wayside (...)

some fell upon stony places (...)

And some fell among thorns (...)

But other fell into good ground

And brought forth fruit. (...)

But he that received seed into the good ground is he that hear the word, and understand it, which also bears fruit and brings forth, some a hundredfold, some sixty, some thirty't

(Mt 13) 
Show us not the aim without the way.

For ends and means on earth are so entangled

That changing one, you change the other too;

Each different path brings other ends in view.

(Ferdinand Lassalle) (Quoted by Sander Griffoen [2012], from

Koestler's [1941] Darkness at Noon)

\section{Introduction and orientation}

It is a true pleasure and an honour to acknowledge Ponti (J.J.) Venter's scholarly work in this Festschrift dedicated to him. If one looks at the broad range of themes that Venter addressed during his career, one of the things that stands out is his extensive publications on and lifelong interest in the normative question of what a university is (see e.g. Venter 1975, 1977, 1978, 1982, 1984, 1994, 1997a, 1997b, 1999, 2006a, 2006b). These publications appeared in scholarly journals from the mid-1970s up to recent times, but those who know Ponti well will be aware of the many other forums (e.g. the BBS - the North-West University's notice board for personnel) in which he wrestled - responding to challenges in various contexts and always willing to engage in a constructive debate with scholars from all fields of study, students and management - with just what a university's task should be.

The largest part of Venter's career was spent at the former Potchefstroom University for Christian Higher Education (PU for CHE). In the early 1970s he studied in Amsterdam at the Free University and, a few years after his return to South Africa, taught at Fort Hare University, situated in what was seen in apartheid South Africa as the 'independent state' of Ciskei. These two events had a significant influence on Venter's own thinking about the task of a university, including the importance of a university's responsible engagement with its context (J.J. Venter pers. comm.., 2013). Ever since Venter was appointed as lecturer in Philosophy at the PU for CHE in 1970 until his retirement four decades later, he struggled to work out such a vision in more detail, often in difficult circumstances. Colleagues such as Bennie van der Walt, Elaine Botha, Lourens du Plessis and others shared Venter's commitment to a wise engagement with their context and provided a valued sense of solidarity, if not uncritical support to his developing thought (Venter 2013). However, it is probably safe to assume that during the last decades of the apartheid era the majority of staff members at the PU for CHE preferred to maintain the political and social status quo and, whilst they may have appreciated Venter's vision of the task of a university, possibly felt ambiguous and uneasy when he did not hesitate to uncover injustices and inward-looking, exclusionary practices revealed by such a vision. When the PU for CHE was superseded by the North-West University, ${ }^{1}$ Venter again probed deeply into its practices, uncovering instances where the university yielded to pressures within a larger ideological context, such as technicism, scientism, economism and neo-pragmatist managerialism. Venter called for a creative humane university, with scholars supporting 'the development of a responsible spirit of renewal of knowledge in their students' (Venter 2006b:357).

1.On 01 January 2004, the PU for CHE merged with the North-West University, incorporating also the staff and students of the Sebokeng Campus of Vista University to form the North-West University (North-West University n.d.).
Venter's struggle to transform his context stems from the Christian-Reformational tradition's emphasis on a transformative engagement with the world. In this article, I will take up this issue in a higher education context. I will argue that, in a higher education context, the Christian-Reformational tradition's engagement with and transformation of culture is particularly strong in its idea of Christian scholarship as the development of a Christian perspective on subject-matter. However, with a few exceptions, there is a lack of emphasis on pedagogy and methods of teaching in a higher education context - this is a neglect which can also be seen happening generally in higher education practice. A lack of critical reflection on how we teach can all too easily and unknowingly lead to exclusionary and unjust practices in the construction of knowledge and also embalm a well-developed perspective that distances one from our world, instead of 'opening up' creation in the particular context of the students.

In this article I aim to contribute to scholarship on Christian higher education by offering suggestions for teaching for a transformative engagement with our context. These suggestions emphasise the importance of care and can be used when teaching both at a university with a Christian identity and at a university with a secular or pluralist identity.

In the first section of the article I point to the needs that currently exist with regard to a Christian pedagogy in higher education. The second section shows how wisdom, creativity and the caritas principle [Christian love of humankind; charity] in science are incorporated into Venter's ideas on the task of a university and responsible scholarship. In the third section, I draw on the work of Venter and others to provide suggestions contributing to a Christian pedagogy in higher education. I argue that responsible scholarship requires that we teach in such a way that students engage with their context and their own learning to wisely understand and transform our world. This means that we should attend to (1) guiding students in caring for the world, (2) unfolding a student's own style of moving between theory and experience, (3) enabling students to experience themselves as academic partners and formative agents, (4) working from a worldview in which the search for change is accompanied by normative sophistication and faithfulness, and (5) forming reflecting teams.

\section{Christian teaching for a transformative engagement in higher education: Pedagogical needs A Christian Reformational approach to transformative engagement}

A transformative engagement with the world is an important theme in the Christian-Reformational tradition. The distinction between worldly concerns and God's kingdom (Eph 2:1-3; Jn 18:35-37; Mt 6:19-21, 6:24-34, 13:44-46) is not taken to mean that Christians should not concern themselves with the problems or delights of this world and pay attention 
only to 'higher', 'spiritual' matters. ${ }^{2}$ On the contrary, such a dualistic view that focuses on Christ apart from culture is criticised (see, for example, the positions of Coletto [2012] and Van der Walt [2001:71-88, 2012:6-9] in response to Niebuhr's [1956] classification of Christian views on the relationship between Christ and Culture; see also Wolterstorff [2002a:30 31]). God's Lordship over all of creation is emphasised ${ }^{3}$ and the neo-Calvinist tradition favours a worldview in which following God's will means obeying God's central love commandment in all aspects of life. God's love is made visible in various laws and norms, sometimes viewed as structural conditions of the cosmos, which invite a person to respond in obedience or disobedience from her or his context. Our fallen world calls out for redemption, made possible through Christ. We are invited to share in this redemption and, through our engagement with the world, to help fulfil its promise in all aspects of life. A person's relationship with God is central in his or her response to these norms and his or her heart, the centre of a person's being, can be directed either towards God as she or he trusts in God's love, or away from God and placing his or her trust in something else, such as an aspect of creation (Clouser 2005; Van der Walt 2010:305-309).

However, the struggle between the two opposing kingdoms is a fault line cutting through everything on earth, including the human heart (Byker 2004; Wolterstorff 1993:268-269). A Christian's response will therefore not always be faithful and obedient; also, even with the best of intentions they can still interpret God's will and God's norms in an incorrect way, causing injustice and suffering to themselves, other people and the world. ${ }^{4}$ In the same way, non-Christians can and do form insights and truths about the world in response to God's norms. The consequences of our responses are helpful pointers: suffering, oppression, and injustice can show us where we interpreted too hastily or took a wrong turn, just as shalom, with its emphasis on relationships enabling human flourishing, indicates that our response is faithful and blessed (Wolterstorff 2004b:141-154, 2004c:124-134).

A transformative engagement with the world is therefore a continuous process dependent on insight through God's grace. We are required to continuously attend to our context, vigilantly looking out for these signs in order to prudently question and enrich our interpretations and practices. In an attitude of humility, Christians should reach out to other people, including non-Christians, to really hear what they have to say, to critically and appreciatively value their insights and carefully look out for pain and suffering, including hurt and harm caused by their own interpretations of God's word and the wrong actions they perform.

2.See, for example, Kuyper ([1931] 1994:30): 'Henceforth the curse should no longer rest upon the world itself, but upon that which is sinful in it, and instead of monastic flight from the world the duty is now emphasized of serving God in the world, in every position in life.

3.In this regard, the following famous quote from Kuyper (1998:488) comes to mind: $\therefore$ there is not a square inch in the whole domain of our human existence over which Christ, who is Sovereign over all, does not cry, "Mine!"'.

4.See, for example, Hart's (1994) discussion of some of the dangers of oppression and exclusion in the thinking of the reformational philosopher Stoker; see also Olthuis's (2012:5-6) explanation of the worldview crisis that can be caused by the clash between 'our implicit emotionally based worldview and our explicitly confessed and articulated worldview'.

\section{A perspectival approach to Christian teaching in higher education: Some dangers}

One can appreciate how claiming God's Lordship over all of human life and viewing humans as homo respondens (Geertsema 1992, 2011; Olthuis 1993; Stoker 1967:158-175; Van der Walt 2013) in all areas of life inspired the development of a worldview and perspective on philosophy in which a coherent conceptual system is cultivated around the relevant norms for all areas of life..$^{5}$ These perspectives are helpful when considering how one should act in a certain context. At the same time, the challenges faced in a particular context require us to revisit our formulation of these norms for it to be relevant to this context. No human constructed system or theory is above critique, as Venter also implies in his distinction between human answering and God's laws and norms to which we answer (see the section 'The task of a Christian university: Venter's perspective on care)'.

The Reformational tradition's development of the idea of Christian scholarship stressed the importance of a Christian perspective on science (Du Plessis 1998:7; Heyns 2013). At institutions of Christian higher education, like the former Potchefstroom University for Christian Higher Education, Christian teaching emphasised a curriculum in which such a perspective on subject-matter is developed. Du Plessis (1998:7), for example, states: 'Die Christelike karakter van die $\mathrm{PU}$ vir CHO word gedemonstreer in die mate wat sy dosente, studente en navorsers ' $n$ Christelike perspektief op en in hulle vakgebiede uitwerk' (original emphasis). ['The Christian character of the PU for CHE is demonstrated in the extent to which its lecturers, students and researchers develop a Christian perspective on and in their respective fields of study'].

This emphasis on a Christian perspective has led to a rich conceptual structure to support scholarly work that acknowledges an integrative, coherent vision of reality in which our response to the law-structure of reality is central. Whilst the Reformational highlighting of learning as a perspectival enterprise is valuable in its denial of a 'neutral' science and the development of a unique Christian voice within the common human practice of scholarship ${ }^{6}$ (see Wolterstorff 2004a:285-286), there are limitations to and dangers in such an approach to Christian teaching.

The emphasis on content perspective might be limiting in the sense that an intellectual, academic understanding is seen as sufficient, with little consideration of how to put such knowledge into concrete action (Van Dyk 2000:23). If Christian scholarship is reduced to a Christian perspective on subject-matter a dualism between theory and practice is likely, where abstract concepts are disconnected from students' and lecturers' daily life (ibid:24).

Furthermore, especially in those Christian institutions where its constituency is perceived as quite homogenous

5.See Dooyeweerd (1955), Stoker $(1933,1967,1970)$ and Strauss $(2009)$ as examples of such an effort.

6.Indeed, it might be argued that such a shared and distinct Reformational perspective was what enabled the vocal and critical minority 'voice of Potchefstroom' to become a voice of conscience within apartheid South Africa. 
and where an inward-looking tradition develops rather than an engagement within a common human practice of scholarship, a perspectival emphasis might tend to become institutionalised and canonised, so that the emphasis is less on learning being 'shaped by our contingent particularities' (Wolterstorff 2004a:286) and more on access control mechanisms which subtly keep out those who might challenge the perspective and status quo. It seems that the more a Christian perspective is identified with a static rational system (often connected to a worldview as a framework of conceptualised beliefs with the hazard of being seen as a set of dogmas) the more likely it is that a hierarchical system will develop where students' contributions to and critique of the particular perspective is delayed until they fully understand such a system. In circumstances like these, critique and possible new contributions are too easily dismissed on the grounds that the particular person simply does not understand 'the theory' or 'the perspective' well enough. Again, a schism between theory and practice can easily develop and urgent appeals to transformative action can be delayed almost indefinitely through a rational system protecting the status quo, rather than serving the Lord. ${ }^{7}$

If Christian teaching in higher education is limited to the teaching of 'the Christian/Reformational perspective' on subject-matter, it poses a threat to a transformative engagement with our world. I agree with Smith (2009:17-19, 228-230) that higher education is not only about information and the development of a Christian perspective but should be re-visioned as a formative project in which both students and lecturers participate. Response-able scholarship should therefore include a careful consideration of the way in which we teach in higher education.

\section{Christian pedagogy in higher education: Needs}

To those of us who are called to walk with God in higher education, the scholars and teachers who are invited to take part in a 'multidimensional, formative (...) activity which gives direction to a person's development by guiding, unfolding and enabling her or him to understand and accept her or his place and calling in God's world' (Van der Walt 2012:12; see also Van Dyk 1997:156-161, 2000:83-109) and to share and open up to students the delights found in learning, to exhibit shalom and equip for shalom (Wolterstorff 2002b:253-264), 'providing' a Christian perspective on subject-matter can clearly never be enough. Indeed, as faithful Christians, one of the important considerations should be how we sow the seeds of the Gospel in our teaching. How do we teach to serve students in learning how to engage with our context in transformative ways? What teaching practices will invite students to participate in the further construction of knowledge whilst drawing on their intimate awareness of their context in order to change our world to be more lifeaffirming, just and caring? In what ways can our teaching open up creation in the particular context of students rather 7.See Hart (1997:19-53 and especially pp. 26-30) for a discussion on the way in which
this spirit of controlling reason shuts down those paths of exploration that cannot be contained in its own bounds. than distancing them from it through a perspective which isolates instead of connects?

Van Dyk's The craft of Christian teaching (2000) and, to a lesser extent, Letters to Lisa (1997), were written in response to the perceived lack of a Christian pedagogy in education (see Van Dyk 2000:xi, 17-19). Van Dyk's integrated approach to Christian teaching and his many excellent concrete suggestions for Christian teaching are helpful in the further development of a Christian pedagogy in which we teach for responsible scholarship and a transformative engagement with our context in higher education. However, his work, as well as contributions by many other Christian educationists in the Reformational tradition, seems to be written largely for Christians teaching at institutions with an explicit Christian identity. ${ }^{8}$ Because most Christians in higher education probably do not teach at Christian institutions, it is important to look at the possibilities and limitations of Christian teaching methods and lecture room structuring in this context as well: it might be a significant aid also for Christians who teach at universities that are now pluralist or secularist but formerly had a strong Christian identity, such as the current North-West University ${ }^{9}$ in South Africa or the Free University in Amsterdam. ${ }^{10}$

Careful reflection on pedagogical issues seems to be side-lined in higher education practice generally. Often, these matters are confined to those academics in Education departments specialising in pedagogy, or else the responsibility for everything that has to do with the how of teaching falls to an Academic Support Services desk providing short training sessions to lecturers interested enough to attend. There appears to be an unspoken 'hands off' agreement between lecturers, where each lecturer is free to teach in whatever way suits her or his preference, as long as it conforms to some external basic requirements and student satisfaction measured by some evaluation form. What is lacking is sustained communal reflection, self-evaluation and a buzzing evaluation by peers with a shared vision. For teachers at higher education institutions with secular or pluralist identities such a gap can present an opportunity to invite colleagues - and perhaps students too - to reflect with them on teaching strategies that encourages students' (and their own) transformative engagement with their context. Such a focus point is relevant to more than just Christian lecturers. Whilst concrete issues can invite shared initiatives in spite of differences of belief, the normative nature of such an investigation naturally leads to questions of trust, hope and religion. This offers Christians a chance to show Christ's love in concrete ways rather than remaining stuck in debates on issues of belief and whether faith has a place at an academic institution. It is also a superb occasion for Christians to learn

8.Van Dyk's (2000:64) view of the ultimate goal of Christian teaching as 'to lead students into knowledgeable and competent discipleship', for example, is not easily translatable into a secular or pluralist setting.

9.The merger referred to in footnote 2 marked the end of the distinct Christian identity of the PU for CHE (see also Froneman 2012).

10.See, for example, Byker's (2004) comments on the changes to the Free University's institutional identity. 
from others, to grow in insight and humility as they are engaging with their context as a shared context, as well as their own learning.

I offer five pedagogical suggestions for a transformative engagement with our context that goes beyond the teaching and development of a Reformational perspective. These suggestions are offered to Christians teaching at higher education institutions with a Christian identity as well as secular and pluralist institutions, and also to those academics who value a scholarly and transformative engagement with their context. In developing these suggestions, I draw on the notion of care and wisdom ${ }^{11}$ developed by Venter, as well as on contributions by Reformational scholars such as Nicholas Wolterstorff ${ }^{12}$ (1993, 2002a, 2002b, 2002c, 2004a, $2004 b, 2004 c)$, Doug Blomberg ${ }^{13}(2005,2007)$ and John van Dyk (2000), and Catholic educationist thinkers Paulo Freire (1970) and Thomas Groome $(1980,1998){ }^{14}$

\section{The task of a Christian university: Venter's perspective on care}

It is impossible to provide a detailed description of Venter's work on the task of a university within the limits and scope of this article. In this section, I will highlight his view on the task of the university as it relates to a transformative engagement with our context and care. Venter (1997a:462, 1977:303) asserts that the heart of the university consists in cultivating responsible scholarship.

Responsible scholarship requires us to distinguish between coherent creaturely conditions for existence and power-exercising patterns (magsuitoefeningspatrone), such as theoretical constructions and rational rule systems (Venter 1975:414-417, 1978:5-50, 1984, 1997a:461-465). This distinction collapsed in the modern era, where the human being as subject conquered the world as picture (Heidegger 1938:85-87) (see also Venter 1997a:456-457, 464-465). In this one-sided view of knowledge, the subject forced nature to answer to its plan for ordering the objective world in rational power systems (Venter 1997a:450, 453-454, 456-459, 464-465, 2006a:312-313). However, if knowledge is seen not primarily as the subject's exercise of his or her power but rather as a gift to be shared, then a caritas principle can form the basis of science.

11. The biblical orientation to wisdom in education (see Blomberg 2005, 2007; Groome $1980,1998)$ is helpful in replacing the theory-practice dichotomy to enable a $1980,1998)$ is helpful in replacing the theory-practice dichotomy to enable transformative engagement with our context. Wisdom is seen as the realisation of value in hearing the callof God, interpreting it in our context to understand what God requires of us, making it present to others in life-giving ways and acting in accord with this.

12.See especially Wolterstorff's idea of teaching for responsible action (Wolterstorff $2004 b, 2004 c$ ) and teaching for justice and shalom, including the cultivation of dispositions to act justly and develop ethical character (Wolterstorff 2002b:264 2002c, 2004b, 2004c).

13.See Blomberg's development of the notion of learning as active responding (Stronks \& Blomberg 1993), his development of Freire's problem-posing approach into a three step model consisting of play, problem-posing and purposeful response (Blomber step model consisting of play, problem-posing and purposeful response (Blomberg 2007:9, 179-212), wisdom as the quest for context-sensitive judgements that leads acknowledging various ways of knowing, or ways of wisdom (Blomberg 2005).

14.Groome $(1980,1998)$ and Van Dyk (2000:183-217) develop further the shared praxis approach of Freire (1970), where students and lecturers grow in wisdom as insights are shared and an attitude of appreciation and respect for various gifts exists.
In responding to norms and natural laws, caritas science aims to unlock conditions for existence in its constructive coherence and in community as part of our responsibility to care for and with others; it is love as 'sharing in caring' (Venter 1997a:463-465, 1997b:25, 1984). It is only when we admit our limitations - we do not possess the world as picture - and carefully look at our constructed rules in dialogical coresponsibility with others that we might be able to see the creaturely conditions for existence in their coherence (Venter 1997a:465). Nevertheless, to develop insight into norms is problematic, argues Venter, as all induction includes a jump (Hume) and norms do not follow from facts (Kant). However, there are warning signs pointing to rule systems that are off course, revealing that we have not really reached the fundamental conditions for existence (Venter 1997a:465). The presence of pain suggests a different concept and formulation of a law of nature and/or a norm and invites us to work on it innovatively-theoretically (Venter 1997a:462-463, 465).

With caritas science, love puts innovation and rule systems in broader context and asks us to consider as many relationships as possible (Venter 1997a:465). Changing or transcending existing relationships creates new meaning, which is the essence of creativity. Creativity should therefore form part of a caritas approach to science and keep up the utopian imagination to think a different world: a world of care and charity (Venter 1997a). It will be helpful to explain our academic processes of knowing in a cultural way, as this will lead to a healthy relativisation of current forms of thinking and understanding (Venter 2006b:363-365).

Venter (1997a:462, 466-467) describes wisdom as the practical side of caritas science and connects it to practice, good sense and discernment. We are not confronted with subject problems only but also with life problems. Education should support students in taking responsibility in response to challenging and real problems (Venter 2006a:314, 1978, 1975:414-417). Theory formation should be filled in with practical experience to enlarge insight into laws and normative rules (Venter 1982, 2006a). However, answers to the following questions cannot be deduced from these norms: In what practical situation(s) should we put the normative insights in action? And how should we do it? Furthermore, sharp insight into theoretical and practical norms (as broad norms valid for a situation) does not guarantee that we will know how to act in a particular situation, or that we would be willing to act in such a way. A healthy tension between the demands of science and the serving of wisdom may help in breaking open the destructive narrowness of abstract science to show ways to wisdom. If we are searching for wisdom in a university context, we should strive towards the cultivation of discretionary power and discernment. It is important to help students understand that science becomes oppressive when it straightjackets reality into a theory and assumes it is, in itself, already wisdom. Students can be made more skilled in recognising pain and suffering, seeing coherences (especially through philosophical and interdisciplinary cooperation) and distinguishing between important and unimportant, good and bad if they are exposed to situations which 
require creative, practical decisions beyond laboratories and computer simulations (Venter 1997a:462, 469, 2006a:305-308). Much more needs to be done about the development of such a way of teaching, concludes Venter.

\section{Teaching for a transformative engagement: Suggestions to explore}

How should we teach in a higher education context where knowledge serves wisdom in not only understanding, delighting in and discovering our world but also in engaging transformatively with the hurt, pain, injustice and hope around us towards healing? In this section, I offer five suggestions for a pedagogy aiming at students' transformative engagement with our context. The first suggestion with its focus on care is explored in detail whereas the other suggestions are described briefly here and discussed in more depth in articles elsewhere.

\section{Guiding students in continuously delving into and acting from their care for the world}

I argue that care deepens wonder and sustains action by continuously calling our imagination to envisage longedfor change both in an academic and in a broader social context. In guiding students' care, lecturers should help them uncover what they care for, explore its emotional landscape and connect it as richly as possible to other forms of care and scholarly endeavours. Five concrete suggestions are offered to support lecturers in guiding students to act from their care for the world. These suggestions refer to the importance of inventory work, the cultivation of empathy, inspiring examples, emotional involvement, and an inner and outer dialogue about the appropriate form their care should take.

\section{Wonder deepened by care}

It is almost platitudinous, but true, to state that for any meaningful teaching to take place, students must be interested in the particular field of study and study material. However important curiosity may be, though, I want to argue that it needs to be deepened and vitalised by care.

We should be critical of the flattening of wonder supported by a pedagogical approach which has been hardened into a few techniques to 'catch' students' attention - catchy video clips at the beginning of a class, cute or funny moving pictures on a PowerPoint ${ }^{\circledR}$ slide to keep students interested, variation in tone and media usage, witty remarks and a good peppering of questions to keep the students at the back from playing with their cell phones. The problem here does not lie so much in what is done than in an acceptance that it is the natural state of students not to be interested in the subject field and that they should be kept entertained or interested by the lecturer in order to complete the course successfully and get value for their money. Whilst such a flat, almost parasitic version of curiosity has certainly become more pressing in the last decade or so, it is clear that such an interest belies the true meaning of the word and is built on a decidedly non- engaging consumer needing to be fed, with interest cynically calculated in terms of what can be gained by either side.

On the other hand, lecturers can guide students to deepen both the playful element in curiosity and the activating element in wonder by connecting it to what students care for. Lecturers can help them uncover what they care for and guide them in exploring it and connecting it to other areas of care. Such a network of care should be explored on as many levels as possible, including its connection to subjectspecific concerns, interdisciplinary considerations, everyday questions as well as the rich emotional tapestry of care.

Heartfelt care sustains wonder. Wonder is then based not only on attraction and intrigue, but also on an attentive 'looking out for' and actively searching for what is best for that or those which one cares for. It can then lead forth our imagination to envisage possibilities for change to be enacted. This is not only an imperative starting point if we want to teach for a transformative engagement with our world but also becomes a sustained source of action which students and lecturers continuously delve into. In this way, caring is made visible as doing ${ }^{15}$.

\section{The role of lecturers in guiding care}

A concern might be raised at this point. A student might care for himself or herself or some group that he or she identifies with or he or she may care deeply for material possessions only. All forms of care should surely not be encouraged? In response, the following need to be highlighted: care and change are normative concepts. ${ }^{16}$ Just as change in itself is not intrinsically good, all manifestations of care are not equally praiseworthy. But action that is not informed by care, because of either a careless approach or inauthenticity, is problematic and dangerous (Buijs 2012:4-9; Venter 1997a, 2006b). Care as such remains an important starting point and sustenance for any form of change.

So, I am not arguing that all care is good care; however, I do argue that care should inform transformative engagement. A lecturer cannot ensure that a student cares in the 'right' way, nor is a lecturer expected to create care where there is none. What a lecturer should do is guide students to uncover what they care for, explore its emotional landscape and connect it as richly as possible to other forms of care and scholarly endeavours. If guided properly, enriched care enlarges students' possibilities for participation in opening up creation in their context and in response to what they care for:

- Initially, a student might identify a sole focus of care, but exploring it may lead to the discovery of further avenues of care. For example, a student seems to care only for material wealth but starts to realise that she or he collapsed care for her or his own well-being into material wealth only and that well-being calls forth an abundance

15.In this regard, see also Blomberg's (2007:200-205) view on wisdom as the realisation of value as related, but with a different emphasis.

16.See also the section 'A worldview in which the search for change is accompanied by normative sophisitication/faithfulness' in this regard - the five main suggestions offered in this article necessarily complement one another. 
of avenues of care in a particular context, including care for others.

- Telling the story of how she or he came to care about specific issues/people/things may lead a student to questions on avenues that she or he did not explore. A neglected area of care might resurface and, along with the possibility of questions as to why it was neglected in the first place, create the opportunity for a broader base of care. For example, a student cares for 'his people', seen as fellow-Afrikaners, but telling the story of the development of his care may reveal the basis of his care to be solidarity with people who are marginalised, which creates the possibility for a broader care-base.

- Having the opportunity to hear other students talk about what they care for (especially in a classroom which is not homogenous in terms of class, race, gender and religion) has great power to call someone's attention to injustices, pain, love and surprising hope that they were previously unaware of. Christians should welcome such an opportunity as a way of becoming aware of others' suffering and helping other students to also become more sensitive to sorrows. In suffering-with others, Christian students can work with fellow students in responding to injustice and suffering. It also provides an opening to show God's care and love, our hope, in concrete terms.

- Guiding students to continuously delve into and act from their care for the world enables Christians to show their care in concrete terms, with a great likelihood of at least some possible connections with the cares of non-Christians, ${ }^{17}$ whilst at the same time opening up opportunities to talk about differences. This provides Christian lecturers and students in secular or plural institutions with the opportunity to integrate their faith with the scholarly work being done at their in institution in an organic way. Such an approach is helpful because it is not preaching from afar; it is not hammering on theoretical arguments to support statements of belief; it is not presented as one perspective to be chosen amongst many; it is not a battle on the field of reason to win over the other side. It meets non-Christians where they are, exactly at the spot where they care for something. Care is central and there is a good chance of agreement on some aspects.

- If what we care for is centre stage, then the discussion in class matters. Even if my worldview differs from another student's worldview, our shared but differently coloured care will make it more likely for me to listen carefully to his or her contributions, taking seriously the suggestions for change and immediately calling forth normative aspects of change. The table is set for a fruitful dialogue: real concerns, high stakes; likely connections in overlapping areas of care; differences arising in what one cares for beyond the overlap as well as in the appropriate

17.This touches on the interactionist model that Wolterstorff (2004c:124-134) uses to describe Christians' way of interacting with other participants. Particularly noteworthy is his suggestion that when Christian critics of social practices speak to society generally (where many members of society do not take the biblical texts as authoritative), they should appeal to whatever ethical convictions they find in as authoritative), they should appeal to whatever ethical convictions they find in
members of society, searching for acknowledgment of the principles they believe correct. action called forth. In evaluating and appreciating various contributions, differences in ultimate commitments will come to the fore in subtle alterations of focus and different forms of care. In discussions like these, the different suggestions for care can be seen as valuable in opening up further suggestions for acting with care with regard to an issue/person/thing dear to both parties.

- This way of guiding students in continually delving into and acting from their care for the world is promising for countering the attitude of friendly indifference sometimes experienced in classes where students' 'own opinion' on social and subject-specific issues, based on their worldviews, is asked for (e.g. in the compulsory Understanding the world modules at North-West University in South Africa ${ }^{18}$ ). Even though students' answers to seemingly topical issues vary widely and often clash head-on, very often no negotiation or real interaction takes place and friendly indifference prevails. It is possible that students' perceptions of political correctness are in cases like this at odds with the intention of a lecturer or institution to acknowledge the role of belief in scholarly work. However, this attitude seems deeply cynical in suggesting that differences in conviction do not really seem to matter all that much, as reality 'outside' goes on regardless of what we believe; it might also be dangerously naive in suggesting that profound differences in world orientation do not suggest real conflict at all.

- A growing awareness of the emotional landscape of care can enable an exploration of that which hinders or prevents you from caring ${ }^{19}$. A purely selfish care or an obsessive care will most likely yield an emotional landscape that is sparsely populated in some parts and over-intense in others. Few and seldom-travelled paths between these areas suggest a resistance to connecting these forms of care with other forms of care unless folding it in on itself. Emotional tension in exploring connections becomes available as working material that can be followed up by students.

\section{Pedagogical suggestions}

How can we teach for a transformative engagement with our context where care informs and sustains our action? What can we do to encourage care that is sensitive to injustice, pain, suffering and hope, whilst at the same time delighting in and discovering in a student's context? The following five concrete pedagogical suggestions may be useful (1) connect their own experience of suffering and hope to what they care for (inventory work); (2) connect the empathy that they feel for others' experience of pain and hope with what they care for (cultivating empathy); (3) show students that active care is possible (inspiring examples); (4) encourage an emotional involvement; and (5) encourage an inner and an outer dialogue as to what form care should take.

18.These compulsory modules were introduced after the former PU for CHE was transformed into the secular North-West University (NWU). According to NWU's vice-chancellor, these compulsory modules continue to allow students' religious perspective to play a role in science via compulsory modules presenting an array of perspective to play a role in science via compulsory modules presentin
religious perspectives and worldviews to choose from (Eloff 2013).

19.In this regard, see Olthuis's (2012:4-5) discussion of expectancy filters. 
Inventory work: To help students uncover and act from their care, the lecturer needs to know them. Ample time should be given for inventory work at the beginning of a module. As every student's journey is important, one needs to know him or her personally in order to serve his or her development well with personalised learning ${ }^{20}$. Some of the questions that are relevant to such inventory work includes: Who are my students? What are their gifts? What are their needs? What are their experiences? What are their interests? What problems and distortions in their lives should we reckon with? (Van Dyk 2000:131-138, 225-227). One can also get to know students better by asking why they are taking the course and why they are at university. It is important to understand that these questions are not merely icebreakers for the students' sake. The answers are important to help a lecturer form a picture of each student.

A lecturer may also enquire into that which moves a student, and ask for personal stories of suffering, rage, hope or inspiration (see also Buijs 2012:7). These kinds of question are probably better placed at a later stage of the module, timed right to tie in with a particular nodal point and after some work in which students have had the chance to witness the lecturer and/or other academics' emotional involvement with the theory and issues. When such stories are shared, the lecturer should clearly communicate his or her respect and appreciation for students' willingness to share their experiences and what they care for with him or her. If a lecturer understands what students care about, these issues can be used as very real and important examples in class. It is also important to remember that a student's experience of sharing these stories, in whatever format, creates a shared space where it is legitimate to care and to struggle with what we care for. This contributes to students' further exploration of how they care and what difference it makes in later class activities, in an organic and non-coercive way, with other students. If a group is expected to work out an answer to a question related to scholarly work, some students might now introduce an aspect of their story, even a turning point, as part of their contribution. To a large extent, the preceding work and the importance it placed on the person reaching out to the greater context made such a growing awareness and shared contribution possible.

Cultivating empathy: If we assume students' humanness, we can cultivate their empathy by sharing other students' and our own stories, but also through exposing them to films, documentaries, photographs and poems in which our humanness is expressed in relation to our world ${ }^{21}$. If lecturers are not too hasty in pointing out the relevance of a film or telling students what they can expect to find in a story and instead listen long and carefully to what it is that appeals to students, they will more likely be rewarded with a layered response and nuances which can be followed up to yield rich and sophisticated responses.

20.See Van Brummelen's (1984:80) discussion of personalised learning

21.Wolterstorff (2004b:151-152) explores the dynamic of empathy as one of the ways of cultivating dispositions in students. The other ways include reasoning, disciplining and modelling.
Inspiring examples: When it comes to caring and acting on care, people are probably to a greater extent moved by real people who inspire than by abstract principles. Lecturers can invite students to share some inspiring examples of care and can also contribute examples of people who cared deeply about both the subject and their context. These examples offered by the lecturer can be deeply influential in creating appreciation, carefulness and humility, as well as in erasing the split between theory and practice and drawing students into the subject field - with their cares. Reflecting on these examples might show how someone's care made her or him search for a solution to a problem with courage, a vision, a calling, conviction and love. It can be shown how such care led to an opening up of a subject field - but it will also make clear that honest, active care does not present a solution to every problem and, indeed, does not always yield normative results. This forms a good starting point for a discussion of what good science is. It will be valuable not to be prescriptive in telling students that 'this is a role model because ...' but rather share the story of a particular person which the lecturer found to be an inspiring example and allow students to respond to this in a way which seems appropriate to them. It is, of course, not necessary that all students feel equally inspired by an example; it can be helpful to understand students and what they care for by exploring why some students feel inspired by a particular person and others not.

Emotional involvement: Care cannot be reduced to its emotional properties, but emotional involvement should be welcomed, as it accompanies care, help sustains challenging work and weaves an intricate pattern of understanding and imagining (Egan 2005; Jensen 2005:68-80). It also opens up connections to their own stories and inspirations, and provides access to their worldviews and a greater understanding of the functioning of their own worldviews (Olthuis 2012).

Inner and outer dialogue on care: It is important to help students open up a space for an inner and an outer dialogue on what they care for and how to care (Buijs 2012). Some students might be hesitant to engage in such a dialogue on care, especially when they see normative issues as decrees from outside which need to be obeyed without question. I do not advocate 'shocking' or 'shaking' students' foundations to put them in a position where they are faced with the vulnerability of their own position. ${ }^{22}$ I fail to see the advantages of a position where students are made to feel confused, vulnerable and seemingly without a riverbank near. The desperate 'sink or swim' feeling caused by this leads to anxiety, which is often countered by clinging to the lifelines thrown by the lecturer. I would much prefer to see a careful, fascinated getting to know about their own inner landscape in discussion with others crossing a different inner terrain but responding to similar issues in their context. Our inner landscape does not speak with one voice; and realising that the various voices might have important messages

22.See, for example, the University of the Free State's teaching approach in a compulsory module to prepare students for life and to develop engaged scholarship: it aims to '.. expose(s) students to provocative questions aimed at disrupting existing knowledge and ways of thinking ...' (University of the Free State n.d.). 
and insights to take note of, as well as finding one's voice amongst them, is a major accomplishment to form the basis for an enriched and authentic engagement with our context and what we care for. As students allow more room for an inner dialogue, there is usually less resistance to hearing other voices from outside, which again can enrich an own response and call forth an own voice.

In this regard, it may be helpful to introduce the following four questions: What are my talents and gifts? What are my interests? What sort of personality do I have? What opportunities am I provided with and with what needs am I confronted? These questions are based on Van Dyk's (2000:36-37) understanding of a person's calling to do something, related to what a person is equipped for. These questions can form part of the inventory work (see above) and it can also accompany students throughout their journey, to be deepened and altered as they read their own stories and emotions in continuous interaction with these answers and other stories.

Keeping a journal where students are invited to respond to a variety of specific questions as well as to the academic texts generally whilst keeping their calling, inspirations and various voices in mind, can be very powerful in helping students to 'see where they are going', especially when they sometimes feel lost or confused. Such a journal strengthens their involvement with their own growth, other's ideas and insights and the scholarly work they are busy with.

\section{Unfolding a student's own style of moving between theory and experience}

In teaching for a transformative engagement with the world, lecturers should help students unfold their own style of moving between theory and experience as they make use of various ways of knowing in developing an appropriate, careful and imaginative response to our world. The unique network of relevant norms facing each person in a particular situation invites someone's whole self to respond. Such a personal engagement cannot but include an imaginative framing and envisioning in which various ways of knowing interact in a multitude of ways (Seerveld 1980:138-155, 2000). Our experience of our context, what makes an appeal to us and how we respond, is opened up by all our ways of knowing. It is therefore important that all our ways of knowing are honoured and that students engage not only with their context but also with their own learning to wisely understand and transform our world. The school system tends to emphasise a theoretical as opposed to a naive way of knowing. University students often excel in theoretical thinking, but can be made aware of multiple ways of knowing (Blomberg 2005; Gardner 2012; McGilchrist 2009), also as different angles of approach, each with its own way of opening up reality in its distancing from concrete experience, as well as its own limitations.

Lecturers can help students by allowing them to make use of various ways of knowing in their exploration and expression of them. Exercises in which an exploration of a particular theme or problem is approached and expressed through more than one way of knowing allow students to compare what is made visible and what is neglected in the respective ways of knowing, as well as what gets lost in translation. Personal preferences, talents, cultural dispositions and a gradual emergence of an own pattern and rhythm of exploration can offer important opportunities for growth when noted in a journal to which the lecturer can also provide feedback. This provides an opportunity for critical reflection on cultural pressures in terms of interpretation, as well as a renewed appreciation of other students' unique style of movement, which contributes to a communal response and engagement with our context and learning.

\section{Enabling students to experience themselves as academic partners and formative agents}

Caring about the world and being aware of one's own style of moving between theory and experience are not enough to enable students to engage transformatively with their context. Responsible scholarship requires them to experience themselves as contributors to academic discussions and as formative agents and partners in our world. Movements such as postmodernism, feminism and post-colonialism highlights exclusionary and unjust practices in the construction of knowledge and sensitise us to the call for recognition from those at the margins. The importance of an inviting psychological and social space in which students feel as if their experience matters and can contribute to our understanding can hardly be overestimated (see Rule 2004), especially in a country like South Africa with its very recent history of marginalisation, also within Christian and Reformational circles.

Lecturers' role in this regard is important, but difficult: all students need to be welcomed in the academic world as partners in understanding and changing our world; we cannot be naive in assuming that all students enter the conversation from equally favourable positions, neither can we assume that we know the various patterns of exclusion well enough from our vantage point. Whilst it may be tempting to ignore conversations dealing with exclusion in an atmosphere of distrust, pointing out exclusionary patterns in academic conversations and its history can actually encourage students to participate in the academic discussion. Assignments in which students can play with different possibilities ('If Kant had lived in a township ...', 'If my parents had had access to Smith's ideas ...') can help to humanise theories, make visible the role of worldview and context in theory, as well as make students aware of the underdetermined nature of theories and more than one 'correct' answer. It may also be helpful if lecturers were to invite students to investigate role models and encourage students to organise themselves into action groups exploring opportunities and risks. If students are to engage with the world in a transformative way, it may be a good idea to invite students' parents, friends or siblings of students to witness and/or take part in some projects. Older students who successfully completed a course can 
also be invited to take part in projects as contributors or supporters, in this way decreasing the possible hierarchical distance between students and academics. Serving students require lecturers to adapt in order to meet students' needs through personalised learning (Van Brummelen 1984:80) and to carefully consider the ways in which peripheral members of the academic community should be invited to participate (Driscoll 2005:164-168).

\section{A worldview in which the search for change is accompanied by normative sophistication/ faithfulness}

A worldview functions at a descriptive and a normative level (Olthuis 1985:3). To pursue an appropriate and faithful response to our convictions as to what the world should be like is often a complex and challenging matter. A Christian pedagogy in which lecturers accompany students as they make decisions should take into account the complexity of and conflicts in a person's worldview. In this regard, we should distinguish and recognise possible tensions between:

- Our worldview and our experience.

- Worldviews and ideologies (Van der Walt 2008:75, 100-101; Goudzwaard, Vander Veenen \& Van Heemst 2007:31-166 on ideologies).

- Manifest and embedded worldviews, where the latter is no longer recognised as a worldview and human assent is masked but still guides our action (Griffioen 2012, 23-51).

- The dimension of a deep, existential commitment and an intellectually coherent system in worldview (Buijs 2012).

- A person's worldview and his or her dissociation from it when she or he enters a social field in which another worldview is embodied (Buijs 2012:3-9).

- Our implicit emotionally based worldview and our explicitly confessed and articulated worldview (OIthuis 2012:5).

With such a multitude of possible tensions, lecturers can serve students by providing space for students to explore the various voices as they search for an authentic way of responding to their context in relationship to what they love. Students' transformative engagement with our context requires that both lecturers and students have an attitude of willingness to engage in an inner (conscience) and outer dialogue, as well as the exploration of patterns of life by means of narratives and personal examples and personal inspiration (Buijs 2012:7-9).

\section{Reflecting teams}

The development of a suitable pedagogy requires lecturers to develop voluntary peer groups organically to reflect on teaching practices that encourage students to engage wisely with and transform our world. Such teams, which can include students, can make use of action research projects that stretch across institutions and specific fields of study to discuss what wise teaching in a specific context means. In this regard, the success of the Project for Enhancing Effective Learning (PEEL), founded in 1985 by teachers and academics as collaborative action-research about their shared concern for passive, independent learning, might offer many ideas to be taken up in a higher education context (see their website http:/ /www.peelweb.org).

\section{Conclusion}

A transformative engagement with our context is a crucial part of a Christian (Reformational) orientation to life. If we follow Venter in viewing responsible scholarship as the task of the university, such an engagement should inform more than just the teaching of a 'Christian perspective' to students, often seen in higher education institutions with a Christian identity. We should serve all students by teaching in such a way that they not only understand but also engage with our context to transform our world as we become aware of suffering, injustice, love and hope. I have suggested that lecturers guide students in continuously delving into and acting from their care for the world by helping students uncover what they care for, exploring its emotional landscape and connecting it to other forms of care and scholarly work. Four further pedagogical suggestions that can be explored further to facilitate students' transformative and wise engagement with our context include unfolding their style of moving between theory and experience through multiple ways of knowing as they imagine appropriate responses to our world; enabling and inviting students to experience themselves as active partners in academic discussions and as formative agents in the world; honouring the complexity in the functioning of students' worldview as they normatively act in and on the world; and the development of peer groups to reflect on teaching practices that encourages higher education students to engage transformatively with their world. These suggestions will probably suit a Christian higher education institution very well but can also be enacted in higher education institutions with a secular or pluralist identity, with resulting new insights through which lecturers - both Christian and non-Christian - can grow.

\section{Acknowledgements Competing interests}

The author declares that she has no financial or personal relationship(s) that may have inappropriately influenced her in writing this article.

\section{References}

Blomberg, D., 2005, 'Ways of wisdom: Multiple modes of meaning in pedagogy and andragogy', in J.H. Kok (ed.), Ways of knowing in concert, pp. 123-164, Dordt College Press, Sioux Center.

Blomberg, D., 2007, Wisdom and curriculum: Christian schooling after postmodernity, Dordt College Press, Sioux Center.

Buijs, G.J., 2012, "Worldview, the credit crisis and the "unity of life". From "framework" to "deep commitment"', Koers - Bulletin for Christian Scholarship 77(1), Art. \#186, 9 pages. http://dx.doi.org/10.4102/koers.v77i1.186

Byker, G.J., 2004, 'Academia coram Deo', in Calvin College, viewed 20 August 2013, from http://www.calvin.edu/convocation/2004-05/september/address_2004sept7.pdf

Clouser, R.A., 2005, The myth of religious neutrality: An essay on the hidden role of religious belief in theories, University of Notre Dame, Notre Dame.

Coletto, R., 2012, 'Christian attitudes in scholarship: The role of worldviews', Koers - Bulletin for Christian Scholarship 77(1), Art. \#33, 10 pages. http://dx.doi.org/ 10.4102/koers.v77i1.33

Dooyeweerd, H., 1955, A new critique of theoretical thought, vols. I-IV, Paideia Press, Jordan Station. 
Driscoll, M. P., 2005, Psychology of learning for instruction, 3rd edn., Allyn \& Bacon, Boston.

Du Plessis, P.G.W., 1998, 'Die PU vir CHO se karakter: Kontinuïteit en oorgang' [The PU for CHE's character: Continuity and transition], Koers - Bulletin for Christian Scholarship, suppl.1, 5-13.

Egan, K., 2005, An imaginative approach to teaching, Jossey-Bass, San Francisco.

Eloff, T., 2013, 'Religie speel ' $\mathrm{n}$ rol by die NWU', in North-West University, besigtig op 30 Augustus 2013, by http://www.nwu.ac.za/af/content/religie-speel-\%E2\%80\%99nrol-die-nwu

Freire, P., 1970, Pedagogy of the oppressed, transl. M.G. Ramos, Continuum, New York.

Froneman, J.D., 2012, 'A vision for a Reformed Christian college for South Africa', Koers - Bulletin for Christian Scholarship 77(1), Art. \#55, 4 pages. http://dx.doi. org/10.4102/koers.v77i1.55

Gardner, H., 2012, 'Multiple intelligences', in YouTube.com, viewed 27 October 2012, from http://www.youtube.com/watch?v=12QtSbP4FRg

Geertsema, H.G., 1992, Het menselijk karakter van ons kennen, Buijten \& Schipperheijn, Amsterdam.

Geertsema, H., 2011, 'Embodied freedom', Koers - Bulletin for Christian Scholarship 75(1), 40-68.

Goudzwaard, B., Vander Vennen, M. \& Van Heemst, D., 2007, Hope in troubled times: A new vision for confronting global crises, Baker Academic, Grand Rapids.

Griffioen, S., 2012, 'On worldviews', Philosophia Reformata 77, 19-56.

Groome, T., 1980, Christian religious education: Sharing our story and vision, HarperCollins Publishers LLC., New York.

Groome, T., 1998, Educating for life, Thomas More, Allen.

Hart, H., 1994, 'Knowing other-wise: A discussion of alterity and the limits of philosophy', Koers - Bulletin for Christian Scholarship 59(3/4), 569-586.

Hart, H., 1997, 'Conceptual understanding and knowing other-wise: Reflections on rationality and spirituality in philosophy', in J.H. Olthuis (ed.), Knowing other-wise: Philosophy at the threshold of spirituality, pp. 19-53, Fordham University Press, New York.

Heidegger, M., 1938, 'Die Zeit des Wiltbildes', in M. Heidegger (Hrsg.), Holzwege, pp. 68-104, Klostermann, Frankfurt.

Heyns, M.F., 2013, 'Skool vir Filosofie, verwelkomingsboodskap van die direkteur', in North-West University, besigtig op 17 Junie 2013, by http://www.nwu.ac.za/af/ content/p-sphil/welc_a.html

Jensen, E., 2005, Teaching with the brain in mind, Association for Supervision and Curriculum Development: Alexandria.

Kuyper, A., [1931] 1994, Lectures on Calvinism: Six lectures delivered at Princeton University under auspices of the L.P. Stone Foundation, Eerdmans, Grand Rapids.

Kuyper, A., 1998, 'Sphere sovereignty', in J.D. Bratt (ed.), Abraham Kuyper: A Centennial Reader, pp. 461-490, Eerdmans, Grand Rapids.

Koestler, A., 1941, Darkness at noon, Macmillan, New York.

McGilchrist, I., 2009, The master and his emissary: The divided brain and the making of the Western world, Yale University Press, New Haven.

Niebuhr, H.R., 1956, Christ and culture, Harper \& Row, New York.

North-West University n.d., The NWU/NWU @ a glance, viewed 19 June 2013, from http://www.nwu.ac.za/content/nwu-glance

Olthuis, J.H., 1985, 'On worldviews', Christian Scholar's Review XIV(2), 1-12.

Olthuis, J.H., 1993, 'Be(com)ing: Humankind as gift and call', Philosophia Reformata 58, 153-172.

Olthuis, J.H., 2012, 'A vision of and for love: Towards a Christian post-postmodern worldview', Koers - Bulletin for Christian Scholarship 77(1), Art. \#28, 7 pages. http:// worldview', Koers - Bulletin for Chris
dx.doi.org/10.4102/koers.v77i1.28

Rule, P., 2004, 'Dialogic spaces: Adult education projects and social engagement', International Journal of Lifelong Education 23(4), 319-334. http://dx.doi.org/ 10.1080/026037042000233476

Seerveld, C., 1980, Rainbows for the fallen world: Aesthetic life and artistic task, Tuppence Press, Toronto.

Seerveld, C., 2000, 'A Christian tin-can theory of the human creature', in C. Bartholomew (ed.), Rainbows for the fallen world: Aesthetic life and artistic task, pp. 138-155, Tuppence Press, Toronto.

Smith, J.K.A., 2009, Desiring the Kingdom: Worship, worldview, and cultural formation, Baker Academic, Grand Rapids.

Stoker, H.G., 1933, Die wysbegeerte van die skeppingsidee, of, grondbeginsels van ' $n$ Kalvinistiese wysbegeerte, De Bussy, Pretoria.

Stoker, H.G., 1967, Oorsprong en rigting, vol. 1, Tafelberg-Uitgewers, Kaapstad.

Stoker, H.G., 1970, Oorsprong en rigting, vol. 2, Tafelberg-Uitgewers, Kaapstad.

Strauss, D.F.M., 2009, Philosophy: Discipline of the disciplines, Paideia Press, Grand Rapids.
Stronks, G.G. \& Blomberg, B. (eds.), 1993, A vision with a task: Christian schooling for responsive discipleship, Baker, Grand Rapids.

University of the Free State n.d., UFS101 prepares new students for life, viewed 22 May 2012, from http://www.ufs.ac.za/templates/archive.aspx?news=2300\&cat=1

Van Brummelen, H., 1984, Walking with God in the classroom, Welch Publishing Company, Burlington.

Van der Walt, B.J., 2001, 'The shape of an integral cosmoscope', in J.H. Kok (ed.), Marginal resistance: Essays dedicated to J.C. Vander Stelt, pp. 71-88, Dordt College Press, Sioux Center.

Van der Walt, B.J., 2008, The eye is the lamp of the body: Worldviews and their impact, Institute for Contemporary Christianity in Africa, Potchefstroom.

Van der Walt, B.J., 2010, At home in God's world: A transforming paradigm for being human and for social involvement, Institute for Contemporary Christianity in Africa, Potchefstroom.

Van der Walt, B.J., 2012, 'Flying on the wings of Vollenhoven's radical Christian worldview: A reconsideration of the usual typology of Christian worldviews', Koers - Bulletin for Christian Scholarship 77(1), Art. \#31, 14 pages. http://dx.doi.org/10.4102/ koers.v77i1.31

Van der Walt, B.J., 2013, "'Homo ludens" of "homo respondens"? 'n Christelikfilosofiese reaksie op ' $n$ hedendaagse idee van die mens as primêr spelende in plaas van 'n antwoordende wese' ["Homo ludens" or "homo respondens"? A Christianphilosophical response to a contemporary view of the human being as primarily a player instead of an answerer], Koers - Bulletin for Christian Scholarship 78(2), Art.\#63, 9 pages.

Van Dyk, J., 1997, Letters to Lisa: Conversations with a Christian teacher, Dordt Press, Sioux Center.

Van Dyk, J., 2000, The craft of Christian teaching: A classroom journey, Dordt Press, Sioux Center.

Venter, J.J., 1975, 'Yesterday and today: The task of the university', Koers - Bulletin for Christian Scholarship 40(4), 402-420.

Venter, J.J. 1977, 'Tension in the Christian university', Koers - Bulletin for Christian Scholarship 42(4), 301-312.

Venter, J.J., 1978, 'De taak van de universiteit', in A. Th. Bruggeman-Kruyff et al. (reds.), De taak van de universiteit, bl. 5-50, Van Gorcum, Assen.

Venter, J.J., 1982, 'Het Filosofie en Vakfilosofie enige betekenis vir beroepsopleiding?' [Does Philosophy have any meaning for career training?], Koers - Bulletin for Christian Scholarship 47(2), 95-110.

Venter, J.J., 1984, 'Kern probleme van die wetenskapmetodologie' [Core problems of science methodology], Koers - Bulletin for Christian Scholarship 49(1), 23-57.

Venter, J.J., 1994, 'Reformational university basis in operation', Orientation: Internationa circular of the Potchefstroom University for Christian Higher Education 71/74, 260-295.

Venter, J.J., 1997a, 'Filosofie en universitêre wetenskapsbeleid: Caritas, sapientia, scientia' [Philosophy and university science policy: Caritas, sapientia, scientia], Koers Bulletin vir Christelike Wetenskap 62(4), 447-473.

Venter, J.J., 1997b, 'Roadsigns to creativity', Analecta Husserliana 53, 3-27.

Venter, J.J., 1999, 'The role of philosophy in the reformational Christian university', Tydskrif vir Christelike Wetenskap 35(3/4), 163-200.

Venter, J.J., 2006a, 'A human(e) "uni-versity": Resisting scientism, technicism, and economism', Koers - Bulletin for Christian Scholarship 71(1), 275-318.

Venter, J.J., 2006b, 'A creative humane university - coping with the business model', Koers - Bulletin for Christian Scholarship 71(2/3/4), 357-395.

Wolterstorff, N.P., 1993, 'The grace that shaped my life', in K.J. Clark (ed.), The spiritual journey of eleven leading thinkers, pp. 266-275, InterVarsity Press, Downers Grove.

Wolterstorff, N.P., 2002a, 'Curriculum: By what standard?', in G.G. Stronks \& C.W. Joldersma (eds.), Educating for life: Reflections on Christian teaching and learning, pp. 17-31 Baker Academic, Grand Rapids.

Wolterstorff, N.P., 2002b, 'Task and invitation', in G.G. Stronks \& C.W. Joldersma (eds.), Educating for life: Reflections on Christian teaching and learning, pp. 253-264, Baker Academic, Grand Rapids.

Wolterstorff, N.P., 2002c, 'Teaching for justice', in G.G. Stronks \& C.W. Joldersma (eds.), Educating for Life: Reflections on Christian teaching and learning, pp. 274-283, Baker Academic, Grand Rapids.

Wolterstorff, N.P., 2004a, 'What is the Reformed perspective on Christian Higher Education?', in C.W. Joldersma \& G.G. Stronks (eds.), Educating for Shalom: Essays on Christian Higher Education, pp. 276-287, Wm. B. Eerdmans Publishing Co., Grand Rapids.

Wolterstorff, N.P., 2004b, 'Teaching for justice: On shaping how students are disposed to act', in C.W. Joldersma \& G.G. Stronks (eds.), Educating for Shalom: Essays on Christian Higher Education, pp. 135-154, Wm. B. Eerdmans Publishing Co., Grand Rapids.

Wolterstorff, N.P., 2004c, 'The project of a Christian university in a postmodern culture', in C.W. Joldersma \& G.G. Stronks (eds.), Educating for Shalom: Essays on Christian Higher Education, pp. 109-134, Wm. B. Eerdmans Publishing Co., Grand Rapids. 